\section{The Master Gardener Program: Do Benefits of the Program Go Beyond Improving the Horticultural Knowledge of the Participants?}

\author{
Roxanne Boyer, ${ }^{1}$ \\ T.M. Waliczek, ${ }^{2}$ and \\ J.M. Zajicek ${ }^{3}$
}

Additional INDEX wOrds. extension program, gardening, quality of life, physical activity, social activity, selfesteem, nutrition

Summary. Texas Master Gardeners participating in an Annual Master Gardener Advanced Training Conference held in College Station, Texas, in June 2000 were asked to complete a survey investigating the impact of the Master Gardener program on perceptions of quality of life and motivations for becoming a Master Gardener. A retrospective pretest/posttest was used to compare the gardeners' current perceptions and their perceptions prior to becoming a Master Gardener. After becoming Master Gardeners, participants reported statistically significant improvements in areas relating to quality of life including physical activity, social activity, self-esteem, and nutrition. Comparisons between demographic characteristics and perceived quality of life scores showed no significant differences. Reasons associated with gaining horticultural information were the primary motivations for becoming a Master Gardener.

Department of Horticultural Science, Texas A\&M University, College Station, TX 77843-2133.

${ }^{1}$ Graduate research assistant.

${ }^{2}$ Assistant professor, Southwest Texas State University, San Marcos, TX 78666.

${ }^{3}$ Professor.
$\mathrm{F}$ or 3 decades Master Gardener volunteers have served the Cooperative Extension Service to meet the growing demands for consumer horticultural information in an increasingly urbanized environment. Originating in Washington in 1972, the Master Gardener program has become popular enough to spread throughout the United States and Canada attracting tens of thousand of volunteers. Many reports focus on what these volunteers give in terms of hours of service and benefits to the extension service. For example, in Texas, Master Gardeners have supplied over \$14.7 million of volunteer service in the past 10 years (Texas Agricultural Extension Service, 1999). The Master Gardeners also benefit from their service in terms of horticultural knowledge gained; however, little research has been conducted regarding the benefits to the Master Gardeners themselves.

Several studies conclude that the number one reason that individuals join the Master Gardener program is to gain horticultural skills (Finch, 1997; Ruppert et al., 1997; Schrock et al., 2000); yet, there is reason to believe that the volunteers receive much more. Volunteering is known to have positive effects on a person's perceived well-being, life satisfaction, and selfesteem (Wilson, 2000; Wilson and Musick, 1999). For older adults, Bradley (1999) finds that volunteering "provides a way to give meaning to their lives," thus improving their sense of well-being.

Research also suggests that many forms of gardening improve a person's perceptions of quality of life. In a study of community garden sites, Waliczek et al. (1996) found that the garden is meeting quality of life needs in terms of self-esteem. Migura and Zajicek (1997) found that female inmates in a federal prison camp significantly increased their self-esteem and life satisfaction scores after participating in a Master Gardener program.

In addition, interaction with nature is known to enhance mental health, reduce stress, and produce such physiological impacts as lower blood pressure and reduced muscle tension (Relf, 1998). In a national survey, participants reported that being around plants made them feel calmer and more relaxed (Relf et al., 1992). Browne (1992) explains that nature can have positive impacts on a person's well being both physically, as a motivator for exercise, and psychologically by providing aesthetic beauty, environmental stimulation, and the opportunity for self-expression and social interaction.

The objectives of this study were to investigate the impact of the Master Gardener program on Master Gardeners' perceptions of quality of life, to describe the demographics of Texas Master Gardeners, and to examine their motivations for becoming Master Gardeners.

\section{Materials and methods}

Sample population. This study was conducted during the Annual Texas Master Gardener Advanced Training Conference held at Texas A\&M University in June 2000. Surveys were distributed during the opening session of the conference and were made available throughout the weekend. The response rate was $45 \%$ with 182 of the 400 overall attendees completing the survey. This level of response was adequate for supplying ideas for the given sample population, but is not necessarily intended for generalizations to other populations.

INSTRUMENTATION. The perceptions of quality of life of Texas Master Gardeners were measured by a questionnaire modified from Migura and Zajicek's (1997) satisfaction of life scale and Waliczek's et al. (1996) quality of life inventory. Both were shown to be valid and reliable in their original studies. A Chronbach's alpha reliability test (Gall et al., 1996) indicated the reliability of the modified survey instrument to be 0.77 .

The questionnaire consisted of two sections. The first section included biographical information and an openended question concerning why subjects became Master Gardeners (Table 1). The second section consisted of 12 quality of life statements within four categories: self-esteem, nutrition, physical activity, and social activity (Table 2).

This section of the instrument was designed as a retrospective pretest to account for response-shift bias that often occurs in self-report measures (Howard and Dailey, 1979). Responseshift occurs when there is a "change in the subject's basis for determining their level of functioning" (Howard et al., 1979). Howard and Dailey (1979) 
Table 1. Biographical information questions for Texas Master Gardeners participating in the Perceived Quality of Life study.

\begin{tabular}{|c|c|c|}
\hline Question & $\begin{array}{c}\text { Frequency } \\
\text { (no.) }\end{array}$ & $\begin{array}{c}\text { Frequency } \\
\text { (\%) }\end{array}$ \\
\hline \multicolumn{3}{|l|}{ What is your highest level of education? } \\
\hline Grade school & 0 & 0.0 \\
\hline Some high school & 0 & 0.0 \\
\hline High school diploma/GED & 0 & 0.0 \\
\hline Professional/trade school & 55 & 30.6 \\
\hline Some college & 57 & 31.7 \\
\hline College degree & 61 & 33.9 \\
\hline Postgraduate work/degree & 7 & 3.9 \\
\hline \multicolumn{3}{|l|}{ Are you employed outside the home? } \\
\hline Not at all & 46 & 26.3 \\
\hline Part-time & 28 & 16.0 \\
\hline Full-time & 39 & 22.3 \\
\hline Retired & 62 & 35.4 \\
\hline \multicolumn{3}{|l|}{ What is your average household income? } \\
\hline$<\$ 25,000$ & 5 & 3.0 \\
\hline$\$ 25,000-\$ 49,000$ & 30 & 18.3 \\
\hline$\$ 50,000-\$ 74,000$ & 51 & 31.1 \\
\hline$>\$ 75,000$ & 78 & 47.6 \\
\hline \multicolumn{3}{|l|}{ What is your ethnicity? } \\
\hline African American & 3 & 1.7 \\
\hline Asian/Pacific Islander & 1 & 0.6 \\
\hline Hispanic & 3 & 1.7 \\
\hline Native American & 3 & 1.7 \\
\hline White, not of Hispanic origin & 164 & 92.1 \\
\hline Other & 4 & 2.2 \\
\hline \multicolumn{3}{|l|}{ What is your age group? } \\
\hline$<25$ & 1 & 0.6 \\
\hline $25-34$ & 0 & 0.0 \\
\hline $35-44$ & 27 & 15.1 \\
\hline $45-54$ & 48 & 26.8 \\
\hline $55-64$ & 57 & 31.8 \\
\hline $65-74$ & 39 & 21.8 \\
\hline $75-84$ & 7 & 3.9 \\
\hline \multicolumn{3}{|c|}{ For how many years have you been a Master Gardener? } \\
\hline $0-5$ & 143 & 78.6 \\
\hline $6-10$ & 33 & 18.1 \\
\hline $11-15$ & 5 & 2.7 \\
\hline $16-20$ & 0 & 0.0 \\
\hline$>20$ & 1 & 0.5 \\
\hline \multicolumn{3}{|l|}{ Did you grow up in a } \\
\hline Rural area & 61 & 35.5 \\
\hline Urban area & 53 & 30.8 \\
\hline Suburban & 58 & 33.7 \\
\hline \multicolumn{3}{|l|}{ Did you garden as a child? } \\
\hline Yes & 128 & 70.7 \\
\hline No & 53 & 29.3 \\
\hline \multicolumn{3}{|l|}{ Why did you become a Master Gardener? ${ }^{\mathrm{z}}$} \\
\hline For horticulture knowledge & 129 & 73.7 \\
\hline To share skills & 57 & 32.6 \\
\hline For a hobby & 35 & 20.0 \\
\hline For social reasons & 15 & 8.6 \\
\hline Because of the influence of a friend & 7 & 4.0 \\
\hline For something to do & 6 & 3.4 \\
\hline To stay healthy & 3 & 1.7 \\
\hline
\end{tabular}

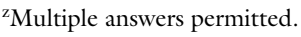

cite an example of a workshop participant who rated her leadership skills as average during a pretest. After participating in leadership training, she learned that her leadership skills were more accurately below average at the pretest. While she experienced a change in her leadership skills, both her pretest and posttest could potentially reflect average ratings. Thus, Howard et al. (1979) recommend that during a posttest, subjects respond twice to items on a self-report measure. Subjects are asked to report their perceptions at present. Then, using the same items, they are asked to refer back to and report their perceptions before the treatment.

The treatment in this study was the subject's experience as a Master Gardener. Subjects were asked to respond to statements regarding their quality of life both before becoming a Master Gardener (before) and at present (now).

The statements were measured on a five point, Likert-type scale (Likert, 1967), where $5=$ strongly agree and 1 = strongly disagree. The points were summed and averaged among all respondents, and each statement was given a quality of life score in both the before and now categories. Additionally, points were summed in each of the four subcategories, and individual statements were given a pretest/ posttest mean score. The higher the score, the more positive the quality of life. Scores ranged from 12 to 60 with a median score of 36 .

Data analysis. Data from the surveys was scanned using Remark Office OMR 4.0 (Principia Products, Paoli, Pa.) and analyzed using the Statistical Package for the Social Sciences (SPSS) for Windows (SPSS, Chicago, Ill.). Statistical procedures included frequencies, paired $t$ tests, and analysis of variance tests to determine differences between scores.

\section{Results and discussion}

Demographic information indicated that a majority of the participants at the seminar were white (not of Hispanic origin) (92\%). Less than 40\% of the participants were employed either full or part-time (38.3\%). Nearly half of the participants reported household income levels of $\$ 75,000$ or more $(47.6 \%)$. The most frequently represented age group was $\mathbf{5 5}$ to 64 year olds (31.8\%). Educational levels of 
Table 2. Paired $t$ test comparison of retrospective pretest and posttest perceived quality of life category scores of Texas $M a s t e r$ Gardeners participatingin the study.

\begin{tabular}{|c|c|c|c|c|c|c|}
\hline $\begin{array}{l}\text { Quality of } \\
\text { lifecategory }\end{array}$ & $\mathbf{n}$ & $\begin{array}{l}\text { Mean } \\
\text { score }^{\mathrm{z}}\end{array}$ & SD & df & $t$ & $\begin{array}{c}P \\
\text { (two-tailed) }\end{array}$ \\
\hline Physical activity (before) & 176 & 12.95 & 1.89 & 175 & -4.788 & $0.000^{* * *}$ \\
\hline Physical activity (now) & & 13.41 & 1.55 & & & \\
\hline Social activity (before) & 174 & 12.21 & 2.09 & 173 & -5.914 & $0.000^{* * *}$ \\
\hline Social activity (now) & & 12.82 & 1.68 & & & \\
\hline Self-esteem (before) & 169 & 11.23 & 1.57 & 168 & -4.768 & $0.000^{* * *}$ \\
\hline Self-esteem (now) & & 11.70 & 1.47 & & & \\
\hline Nutrition (before) & 175 & 11.75 & 2.38 & 174 & -5.728 & $0.000^{* * *}$ \\
\hline Nutrition (now) & & 12.42 & 2.04 & & & \\
\hline Total (before) & 167 & $48.19^{y}$ & 5.86 & 165 & -6.938 & $0.000^{\star \star *}$ \\
\hline Total (now) & & $50.34^{y}$ & 4.68 & & & \\
\hline
\end{tabular}

${ }^{\mathrm{z} S c o r e s}$ range from 3.00 to 15.00 .

yScores range from 12.00 to 60.00

${ }^{*},{ }^{* *},{ }^{* \star *}$ Statistically significant at $P \leq 0.05,0.01$, or 0.001 , respectively.

Master Gardeners were relatively equally distributed among having some college $(30.6 \%)$, a college degree $(31.7 \%)$, and postgraduate work (33.9\%) (Table 1). These findings are similar to other Master Gardener studies. In Bexar County, Texas, Finch (1997) reported the most active Master Gardeners to be white, older, and as having resided in higher income neighborhoods. However, the older group in his study was 45 to 54 years of age. Schrock et al. (1999) found that Missouri Master Gardeners were well-educated, moderately wealthy, and over half were 50 years of age or older. Rohs and Westerfield (1996) reported that $55 \%$ of the Master Gardeners in Atlanta, Georgia were over 50 years of age, $52 \%$ reported incomes of $\$ 50,000$ or more, and $41 \%$ had completed some college, while 35\% had a college degree.

When asked, Why did you become a Master Gardener?, 73.7\% of the respondents listed reasons associated with gaining horticultural knowledge. Finch (1997), Ruppert et al. (1997), Rohs and Westerfield (1996), and Schrock et al. (2000) all report the desire for horticultural knowledge as one of the main reasons for joining the Master Gardener program. The next most common answer in the current study was to share skills with others and give back to the community $(32.6 \%)$. This finding is similar to that of Bradley (1999) who, in a review of research involving older adults, reported, "Probably the most prevalent reason given for volunteering reflects the idea that individuals want to make a difference in the community in which they live." Other reasons given for becoming a Master Gardener in this study included for a hobby $(20 \%)$; to socialize with other gardeners $(8.6 \%)$; because of the influence of a friend (4\%); to have something to do with their time $(3.4 \%)$; or to stay healthy (1.7\%).

Most of the respondents in this study $(78.6 \%)$ had been participating in the Master Gardener program for $\mathbf{5}$ years or less. Most had gardened as children $(70.7 \%)$ in rural, urban, and suburban areas $(35.5 \%, 30.8 \%$, and $33.7 \%$, respectively).

Statistically significant improvements were found in the perceptions of quality of life of Master Gardeners after becoming a Master Gardener. Scores on the posttest (now) were significantly higher than on the retrospective pretest (before). These increases were consistent in all four quality of life categories indicating improvements in perceptions of physical and social activity, self-esteem, and nutrition (Table 2). Due to this finding, additional comparisons were made between individual statements on the pretest and posttest. All statements on the posttest had significantly higher scores than on the pretest with the exception of the statement "I prefer to be by myself." The average score on this statement showed a statistically insignificant decrease from the pretest to the posttest, indicating a trend away from wanting to be by oneself after becoming a Master Gardener (Table $3)$. This finding supported past research studies that found that gardening promotes social interaction (Waliczek et al., 1996).

Comparisons were also made between demographic variables and posttest (now) scores (Table 4). There were no significant differences between quality of life scores and any demographic characteristics. This indicated that, for this particular sample, the activity of volunteering as a Master Gardener crossed age, educational, and socioeconomic boundaries. This finding supports research by Charles Lewis who also asserts, "plants are nonjudgmental, nonthreatening, and nondiscriminating” (Lewis, 1996).

These results have implications for both the Texas Cooperative Extension Service and the area of peopleplant interaction research. To date, the cooperative extension service has promoted the Master Gardener program for its benefit to communities and its educational value to the individual Master Gardener. Results from this study, however, indicate that the value to the individual gardener goes beyond educational benefits to include improvements in physical and social activity, self-esteem, and nutrition (Table 2).

The Master Gardener program provides an individual with the opportunity for volunteering. Volunteering in almost any capacity brings value to the individual and contributes to positive feelings of life-satisfaction, selfesteem, and self-rated health (Wilson, 2000). These benefits can be especially important to older persons who may have experienced a role loss because of retirement or widowhood (Wilson and Musick, 1999). Master Gardeners may also experience a sense of validation through teaching, socializing with others who have similar interests, and participating in activities they enjoy. In addition, the evidence 
Table 3. Paired $t$ test comparison of retrospective pretest and posttest individual perceived quality of life statement scores of Texas Master Gardeners participating in the study.

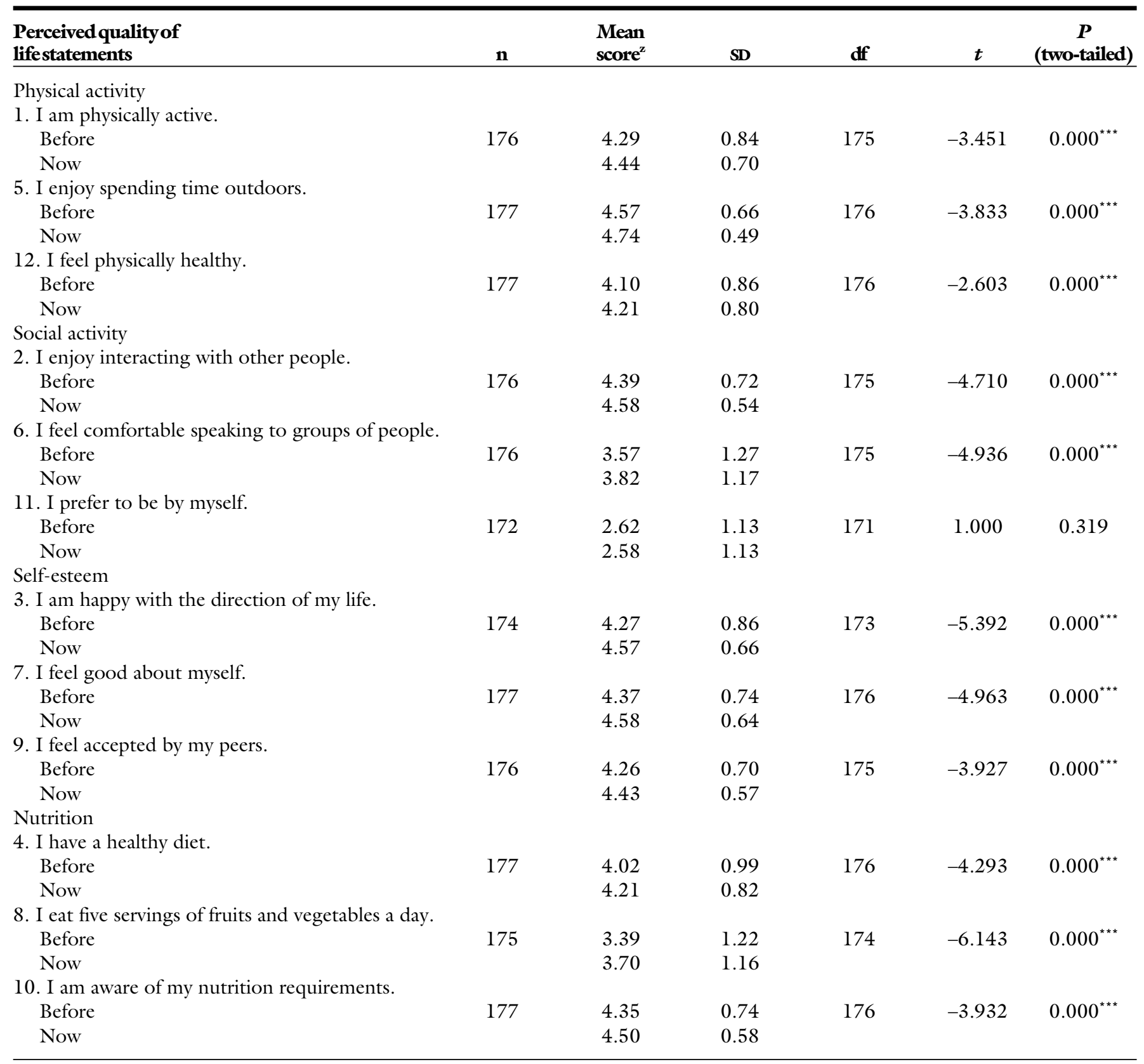

${ }^{\mathrm{z}}$ Scores range from 1.00 to 5.00

$\stackrel{*, \star \star, * \star \star}{ }$ Statistically significant at $P \leq 0.05,0.01$, or 0.001 , respectively.

in this study supports other findings that gardening itself can improve a person's perceptions of quality of life (Browne, 1992; Waliczek et al., 1996; Migura and Zajicek, 1997).

Thus, the Master Gardener program offers much more to its participants than just horticultural information. Matsuo (1992) proposes that our life is full of the "behavior of acquiring objects but lacking in that of fostering life." For those interested in both gardening and fostering life, the Master Gardener program provides that opportunity.

\section{Literature cited}

Bradley, D.B. 1999. A reason to rise each morning: The meaning of volunteering in the lives of older adults. Generations 23(4):45-50.

Browne, C.A. 1992. The role of nature for the promotion of well-being of the elderly, p. 75-79. In: D. Relf (ed.). The role of horticulture in human well-being and social development. Timber Press, Portland, Ore.

Finch, C.R. 1997. Profile of an active Master Gardener chapter. HortTechnology $7(4): 371-376$.
Gall, M.D., W.R. Borg, and J.P. Gall. 1996. Educational research: An introduction. Longman Publ., White Plains, N.Y.

Howard, G.S. and P.R. Dailey. 1979. Response-shift bias: A source of contamination of self-report measures. J. Appl. Psychol. 64(2):144-150.

Howard, G.S., R.R. Schmeck, and J.H. Bray. 1979. Internal invalidity in studies employing self-report instruments: A suggested remedy. J. Educ. Measurement 16(2):129-135.

Lewis, C.A. 1996. Green nature/ human nature: The meaning of plants in our lives. Univ. Ill., Chicago. 
Regearch Reports

Table 4. Analysis of variance comparison of the demographic variables and the posttest perceived quality of life scores of Texas Master Gardeners participating in the study.

\begin{tabular}{|c|c|c|c|c|c|c|}
\hline Demographicvariable & $\mathbf{n}$ & Mean score $^{\mathrm{z}}$ & SD & df & $\mathbf{F}$ & $\boldsymbol{P}$ \\
\hline \multicolumn{7}{|l|}{ Ethnicity } \\
\hline African American & 3 & 47.67 & 7.09 & 5 & 0.964 & 0.442 \\
\hline Hispanic & 3 & 53.33 & 2.08 & & & \\
\hline Native American & 3 & 48.33 & 4.93 & & & \\
\hline White & 153 & 50.33 & 4.70 & & & \\
\hline \multicolumn{7}{|l|}{ Highest level of education } \\
\hline Some college & 52 & 50.31 & 4.65 & 3 & 0.217 & 0.884 \\
\hline College degree & 53 & 50.30 & 4.53 & & & \\
\hline Postgraduate work/degree & 56 & 50.59 & 5.03 & & & \\
\hline Professional/ trade school & 7 & 51.71 & 3.73 & & & \\
\hline \multicolumn{7}{|l|}{ Household Income } \\
\hline
\end{tabular}

Likert, R. 1967. The method of constructing an attitude scale, p. 90-95. In: M. Fishbein (ed.). Readings in attitude theory and measurement. Wiley, New York.

Matsuo, E. 1992. What we may learn through horticultural activity, p. 146-148. In: D. Relf (ed.). The role of horticulture in human well-being and social development. Timber Press, Portland, Ore.

Migura, M.M. and J.M. Zajicek. 1997. Research tools for evaluating the effects of a vocational horticulture program on the self-development of female inmates. HortTechnology 7(3):305-308

Relf, D., A.R. McDaniel, and B. Butterfield. 1992. Attitudes toward plants and gardening. Hort Technology 2(2):201-204.
Relf, D. 1998. People-plant relationship, p. 21-42. In: S.P. Simson and M.C. Straus (eds.). Horticulture as therapy. Food Products Press, New York.

Rohs, F.R. and R.R. Westerfield. 1996. Factors influencing volunteering in the Master Gardener program. HortTechnology 6(3):281-285.

Ruppert, K.C., J. Bradshaw, and A.Z. Stewart. 1997. The Florida Master Gardener program: History, use, and trends. HortTechnology 7(4):348-353.

Schrock, D.S., M. Meyer, P. Ascher, and M. Snyder. 1999. Missouri Master Gardener demographics. J. Ext. 37(5). 29 Apr. 2002. <http://.joe.org/1999 october/rb4.html>.
Schrock, D.S., M. Meyer, P. Ascher, and M. Snyder. 2000. Reasons for becoming involved as a Master Gardener. HortTechnology 10(3):626-630.

Texas Agricultural Extension Service. 1999. Annual report. Texas A\&M Univ., College Station.

Waliczek, T.M., R.H. Mattson, and J.M. Zajicek. 1996. Psychological benefits of community gardening. J. Environ. Hort. 14(4):204-209.

Wilson, J. and M.A. Musick. 1999. The effects of volunteering on the volunteer. Law and Contemporary Problems 62(4):141-168.

Wilson, J. 2000. Volunteering. Annu. Rev. Sociol. 26:215-240. 